\title{
Dynamic Inundation Simulation of Storm Water Interaction between Sewer System and Overland Flows
}

\author{
Ming-Hsi Hsu, Shiuan-Hung Chen and Tsang-Jung Chang \\ Dept. of Bioenvironmental Systems Engineering, National Taiwan University \\ 1, Roosevelt Rd. Sec.4, Taipei, Taiwan, R.O.C. 10617 \\ Keywords: Urban inundation model, Storm Sewer System. Overland Flow
}

\begin{abstract}
An improved urban inundation model, coupling a 2D non-inertia overland flow model with a storm water management model, is adopted to simulate inundation in urban areas. The model computes, not only the overland runoff and the water overflow through manholes where surface runoff exceeds the capacity of storm sewers, but also the bidirectional flow interactions between sewers and overland runoff. The model was verified by a typhoon event in Nov. 2000, which resulted in serious inundation in the Mucha area of Taipei City. The result shows that the present model indeed improves simulation accuracy over the earlier model, and can be used to provide a more reliable flood mitigation design.
\end{abstract}

\section{INTRODUCTION}

In urban areas, storm sewer systems are widely adopted for reducing surface runoff. Many numerical models have been built for flow computation in sewer systems. Stephenson (1981), Yen (1986), and Yen and Akan (1999) had excellent reviews of storm sewer modeling. Meanwhile, several studies (Lager and Smith, 1974; Huber, 1975; Marsalek et al., 1975) compared the model simulation and field observation results for various urban areas, and found that the agreement was good for ILLUDAS (Terstriep and Stall, 1974) and SWMM (Huber and Dickinson, 1988). Due to the limited capacities of inlets or conduits, the sewer systems are not always able to carry all the 
runoff. As a result, inundation takes place if the water overflows from sewer system at surcharged manhole. The excess water, including the rainfall excess and surcharged flow from sewer system, becomes surface runoff flowing on the surface toward lowlands until it reaches another under-capacity drainage inlet.

Since both overland and sewer flows are generally unsteady, non-uniform and spatially varied (Akan, 1993), various numerical methods were developed based on different assumptions to simplify the complex physical processes. These models may generally be classified into three categories. The most common category, used by much commercial software like MOUSE (DHI, 2000) and HYDROWORKS (Wallingford Software Ltd, 2000), is to begin with the simulation of the sewer flows by using a sewer model to obtain the discharge hydrographs at surcharged manholes. As shown in Fig. 1-a, surface inundation depth is then determined by water level or conceptual volume-depth rating curves. No dynamic computation of overland flow is performed.

Hsu et al., (2000) developed an urban inundation model combining a storm sewer model, SWMM, and a 2-D diffusive overland-flow model to simulate surcharge-induced inundation in urban areas. The model may be classified as a second category that treats the water in the sewer system and on the ground surface separately. The model assumes that the surcharge-induced overland-flow does not return to the sewers, as shown in Fig. 1-b, except at the locations of pumping stations. For cases with smooth topology, this assumption has little influence on the simulation accuracy. However, for regions with local depressions, the interaction between surface runoff and sewer flow is bidirectional. The water does not only overflow from the surcharged sewers but may also flow back to the sewers. If bidirectional processes are neglected, the surcharged water would be shown as accumulating in the depressions and unable to 
Please cite as: Hsu MH, Chen SH, Chang TJ. (2002) Dynamic inundation simulation of storm water interaction between sewer system and overland flows, Journal of The Chinese Institute of Engineers, 25(2) 171-177. DOI:10.1080/02533839.2002.9670691

drain. For this reason, the flood extent is overestimated.

Djordjević et al. (1999) tried an approach of a third category by using the concept of dual drainage. Bidirectional water movement between overland flow and sewer flow is considered. In Djordjević's model, the surface water levels in subcatchments are determined by simplified stage-volume functions and the surface runoff between subcatchments flows through a pre-determined surface flow path network. The flood information is lumped and unable to reflect the water movement within a subcatchment.

This study improves on the inundation model of Hsu et al. (2000) by coupling the overland and sewer flow models. As shown in Fig. 1-c, the improved urban inundation model allows for the surcharged water to reenter the sewer system through manholes which are unsurcharged. Comparing to Hsu et al. (2000), the newly developed model better simulates the real physical phenomena.

\section{METHODOLOGY}

To describe water movements between overland flow and sewers, the improved urban inundation model is developed by coupling a 2D non-inertia overland flow model with the EXTRAN block of SWMM. Furthermore, some modification is required of the original EXTRAN programming codes in order to compute overland and sewer flow iteratively.

\section{Governing Equations}

In the 2D non-inertia overland flow model, the inertial term in momentum equations is neglected based on the assumption that the acceleration term is small compared with the gravitation and friction terms. The depth-averaged shallow water equations on the overland surface are written as: 


$$
\begin{gathered}
\frac{\partial d}{\partial t}+\frac{\partial[(1-\beta) u d]}{\partial x}+\frac{\partial[(1-\beta) v d]}{\partial y}=q_{s}(x, y, t)-q_{i}(x, y, t) \\
-\frac{\partial h}{\partial x}=S_{f x}+\frac{\left[q_{s}(x, y, t)\right] u}{g d} \\
-\frac{\partial h}{\partial y}=S_{f y}+\frac{\left[q_{s}(x, y, t)\right] v}{g d}
\end{gathered}
$$

where, $d=$ the water depth, $\beta=\sqrt{A_{b} / A}$ detaining ratio which represents a linear ratio of building area to the total area of interest. $u$ and $v$ are the velocity components in the $\mathrm{x}$ and $\mathrm{y}$ directions, respectively, $h=d+z$ the water surface elevation, $S_{f x}=\frac{n^{2} u \sqrt{u^{2}+v^{2}}}{d^{4 / 3}}$ and $S_{f y}=\frac{n^{2} v \sqrt{u^{2}+v^{2}}}{d^{4 / 3}}$ the friction slopes along the $\mathrm{X}$ and y directions, respectively. $q_{s}(x, y, t)$ and $q_{i}(x, y, t)$ are the rate of water entering and leaving ground surface per unit area, which are expressed as

$$
\begin{gathered}
q_{s}(x, y, t)=I(x, y, t)+\sum_{k} Q_{s}\left(x_{k}, y_{k}, t\right) \delta\left(x-x_{k}, y-y_{k}\right) \\
q_{i}(x, y, t)=\sum_{k} Q_{i}\left(x_{k}, y_{k}, t\right) \delta\left(x-x_{k}, y-y_{k}\right)
\end{gathered}
$$

in which, $I(x, y, t)=$ the rainfall excess intensity, $Q_{s}\left(x_{k}, y_{k}, t\right)=$ the outflow discharge from surcharged manhole of drainage sewer, $Q_{i}\left(x_{k}, y_{k}, t\right)=$ the inlet discharge of drainage system, where the outflow discharges and inlet drainages which occur in sewer systems are considered as point sources and sinks in 2D overland flow, and $\delta$ is the Dirac delta function.

In Eqs. (2) and (3), it is assumed that the influx direction of rainfall or manhole effluent is normal to the overland surface and the inlet drainage leaves with practically the overland flow velocity components $u$ and $v$ (Abbott, 1998). The unknowns $d$, 
$u$ and $v$ in Eqs. (1) to (3) are solved by an alternating direction explicit scheme. The derivation of finite difference equations was depicted in the authors' earlier study (Hsu et al., 2000).

\section{Flow Interaction}

To simulate the flow interactions between the sewer system and the ground surface, the overflow from surcharged manhole to ground surface and drainage through inlet to sewer system are used for model linkage. The overflow from surcharged manhole $Q_{s}\left(x_{k}, y_{k}, t\right)$ is calculated by the EXTRAN block. On the other hand, the surface flow intercepted and directed to the sewer system is called the inlet discharge. The surface runoff is collected by the inlets and drains to the sewer system through the manhole junction that the inlet connects to. There are various types of inlets, e.g., curb-opening inlet, gutter inlet and grated inlet (Linsley et al., 1992), used in urban drainage. The inlet capacity can be determined based on its design. When no surcharge is occurring, the overland flow usually drains at the discharge of inlet capacity unless the flow rate is over the design capacity. The inlet discharge $Q_{i}\left(x_{k}, y_{k}, t\right)$ is expressed as follows,

$$
Q_{i}\left(x_{k}, y_{k}, t\right)=\min \left[\frac{\partial d\left(x_{k}, y_{k}, t\right)}{\partial t}, Q_{d}\left(x_{k}, y_{k}\right)\right]
$$

where, $d\left(x_{k}, y_{k}, t\right)$ is the water depth at location $\left(x_{k}, y_{k}\right)$ and time $t, Q_{d}\left(x_{k}, y_{k}\right)$ is the design capacity of the inlet at location $\left(x_{k}, y_{k}\right)$, which is a given constant. In a case in which the manhole where the inlet connects to is unsurcharged, the water drains with the rate $Q_{i}\left(x_{k}, y_{k}, t\right)$ shown in Eq. (6). In contrast, if the manhole is surcharged, which implies that the water is surcharging to the surface instead of entering the sewer, the inlet discharge $Q_{i}\left(x_{k}, y_{k}, t\right)$ is set to zero. 


\section{MODEL VERIFICATION}

The Mucha area, located in the southern part of Taipei City (Fig. 2), is surrounded by hills on the north and by flood levees along the Chin-Mei Creek on the east, south and west sides. The region is an isolated urban drainage area due to its geographic conditions, and taken as the study area for the present model. Four pumping stations, numbered PS1 - PS4, were built to drain the runoff out of the area with design capacities of $4.0,8.0,15.0$ and $12.0 \mathrm{~m}^{3} / \mathrm{s}$, respectively.

In November 2000, the Mucha area was seriously inundated as a result of the Typhoon Xangsane. The event was taken for model verification. There was $504.5 \mathrm{~mm}$ total rainfall in 24 hours. The rainfall hyetograph is shown in Fig. 3, with a peak intensity of $68 \mathrm{~mm} / \mathrm{h}$ during the event. There was no measuring equipment to record the inundation area or water depth during the flood. However, the inundation zones were surveyed and delineated by the Taipei City Government after the event. The flood extent established by the post-event survey is illustrated in Fig. 4 and the simulated result by the present model is shown in Fig. 5. The comparison of simulation result and surveyed inundation zones reveals that most inundation situations have been properly simulated by the model.

\section{DYNAMIC WATER INTERACTIONS}

The improved urban inundation model simulates the flow interaction between sewer system and overland surface by allowing bidirectional flows between them, while the earlier model of Hsu et al. (2000) does not allow for surcharge water to reenter the sewer system. The temporal variations of total inundation volumes predicted by the two models are plotted in Fig. 6. It shows that the earlier model's failure to simulate surcharged water reentering the sewer system results in over estimation of total 
Please cite as: Hsu MH, Chen SH, Chang TJ. (2002) Dynamic inundation simulation of storm water interaction between sewer system and overland flows, Journal of The Chinese Institute of Engineers, 25(2) 171-177. DOI:10.1080/02533839.2002.9670691

inundation and flood duration.

There are three local depressions, marked as A, B and C in Fig. 5, seriously inundated during the event. Fig. 7 compares the inundation depth hydrographs calculated by the two models at point $\mathrm{A}$, which is located in a local depression with manholes. As shown in Fig. 8, there are 5 manholes, Nos. 1003, 1004, 1007, 1008 and 1009 , near the depression point $\mathrm{A}$. The ground elevation of point $\mathrm{A}$ is $0.95 \mathrm{~m}$ lower than the outlet point near the manhole No. 1009. Therefore the surcharge water will stay there unless reentering the sewer system is simulated. The simulation result in Fig. 7 shows that point A was not inundated until the $8^{\text {th }}$ hour, namely, the design capacity of the sewer system was capable of draining the runoff and no manhole in the depression was surcharged. Point A began to be inundated from the $8^{\text {th }}$ hour due to the intensity of rainfall and upstream conduit discharge. The rainfall intensity during the $9^{\text {th }}$ to the $11^{\text {th }}$ hour was lower than before the $8^{\text {th }}$ hour, the sewer system was capable of draining the surcharged water out of the depression. In the present model, the physical process of surcharged water reentering the sewer system was well simulated, and the inundation depth began to decrease at the $9^{\text {th }}$ hour. However, in the earlier model, the surcharged water was distributed to the area of depression instead of being drained out, and thus the inundation depth remained high.

At the $12^{\text {th }}$ hour, the rainfall intensity increased and the surcharge occurred again, lasting to the end of the event. The surcharged water quickly drained out, within 6 hours of the rainfall ending. In contrast, the earlier model allows only the water above the outlet stage to flow out of the depression, the rest staying trapped in the depression. As a result, the final inundation depth at point $\mathrm{A}$ is $0.95 \mathrm{~m}$ (shown in Fig. 7), the elevation difference between point $\mathrm{A}$ and the outlet point of the depression. Fig. 7 also indicates 
that the present model predicts a higher inundation depth than the earlier model during hours 18 to 27 . This is a result of sewer system interaction. The upstream conduit discharge increased due to the runoff that flowing back to sewers at upstream unsurcharged inlets from overland flow caused by other surcharged manholes, thus the surcharge increased and caused more serious inundation at point $\mathrm{A}$.

Fig. 9 presents the inundation depth hydrograph at point $\mathrm{B}$, which is located in a local depression without a manhole. The ground elevation and the maximum inundation depth in the region nearby point B are plotted in Fig. 10, it indicates that the elevation at point $\mathrm{B}$ is about $0.7 \mathrm{~m}$ lower than the outlet point.

In the earlier model, the surcharged water from manholes outside the depression started converging on the region at the $8^{\text {th }}$ hour. As shown in Fig. 9, the water lower than the depression outlet was then trapped. On the contrary, the simulation of the present model indicates that the initial surcharge water was captured by other unsurcharged inlets and reentered the sewer system until those inlets were also surcharged after the $18^{\text {th }}$ hour. Similar to point A, the water flooding the depression was completely drained by the $29^{\text {th }}$ hour. Meanwhile, point B was inundated from the $20^{\text {th }}$ to $28^{\text {th }}$ hours with a deeper inundation. Again, this is due to the surcharge increased by the flow returning to the sewer system at upstream unsurcharged inlets.

Fig. 11 displays the hydrographs at point $\mathrm{C}$, which is located in a local depression with neither manhole nor upstream catchment. As shown in Fig. 12, the elevation at point $\mathrm{C}$ is $0.93 \mathrm{~m}$ lower than the depression outlet. The inundation of the depression was caused by the surcharge from the first downstream manhole, numbered No. 1005, as well as the local excessive rainfall. The earlier model's result, similar results for points $\mathrm{A}$ and $\mathrm{B}$, indicates that the manhole surcharge converged into the depression and 
trapped. However, the present model shows that most of the surcharge was captured by other inlets and directed to downstream manholes other than No.1005. In addition, since there is no upstream manhole above manhole No. 1005, the discharge was hence less than the one calculated by the earlier model, and the predicted inundation depth was shallower.

\section{CONCLUSION}

An urban inundation model was improved to account for dynamic flow interactions between the sewer system and the ground surface. The present study investigates the interactive phenomena between the sewer system and overland flow, and refines an earlier model to give more reasonable simulation results. Due to the fact that water can be drained out through inlets when the sewer capacity is available, the flood durations in depression regions predicted by the improved model are shorter than simulated by the earlier model. The maximum inundation depths were predicted to be shallower in upstream local depressions. However, in depressions with upstream manholes, the surcharge may be increased by the flow that reenters the sewers at upstream inlets which are unsurcharged. Therefore, the maximum inundation depth could be underestimated without taking the dynamic water interaction into consideration.

\section{ACKNOWLEDGEMENT}

The work reported herein was supported by the National Science Council of Taiwan, Republic of China, under grant NSC 89-2625-Z-002-057. Their support is gratefully acknowledged. The authors are grateful to Professor A. Y. Kuo of National Taiwan University for valuable suggestions. 
Please cite as: Hsu MH, Chen SH, Chang TJ. (2002) Dynamic inundation simulation of storm water interaction between sewer system and overland flows, Journal of The Chinese Institute of Engineers, 25(2) 171-177. DOI:10.1080/02533839.2002.9670691

\section{REFERENCES}

1. Abbott, M. B., 1998, Computational Hydraulics. Ashgate Publishing Company, Vermont. $2^{\text {nd }}$ ed., pp. 59-62.

2. Akan, A. O., 1993, Urban Stormwater Hydrology. Technomic Publishing Co., Inc., Lancaster, PA, U.S.A.

3. Danish Hydraulic Institute, 2000, MOUSE Ver. 2000, User's Manual. Hørsholm, Denmark.

4. Djordjević, S., Prodanović, D., and Maksimović, Ć., 1999, “An Approach to Simulation of Dual Drainage." Water Science Technology, Vol. 39, No. 9, pp. 95-103.

5. Hsu, M. H., Chen, S. H., and Chang, T. J., 2000, "Inundation Simulation for Urban Drainage Basin with Storm Sewer System.” Journal of Hydrology, Vol. 234, No. 1-2, pp. 21-37.

6. Huber, W. C. and Dickinson, R. E., 1988, Storm Water Management Model. User's Manual Ver. IV. U. S. Environmental Protection Agency.

7. Huber, W. C., 1975, Model for Storm Water Strategies. APWA Reporter.

8. Lager, J. A. and Smith, W. G., 1974, Urban Stormwater Management and Technology - An Assessment. U. S. Environmental Protection Agency Report, EPA $-67012-74-040$.

9. Linsley, R. K., Franzini, J. B., Freyberg, D. L., and Tchobanoglous, G., 1992, Water-Resources Engineering, McGraw-Hill, Inc., New York.

10. Marsalek, J., Dick, T. M., Wisner, P. E., and Clarke, W. G., 1975, "Comparative Evaluation of Three Urban Runoff Models." Water Resources Bulletin. AWRA, 
Please cite as: Hsu MH, Chen SH, Chang TJ. (2002) Dynamic inundation simulation of storm water interaction between sewer system and overland flows, Journal of The Chinese Institute of Engineers, 25(2) 171-177. DOI:10.1080/02533839.2002.9670691

Vol. 11, No.2.

11. Stephenson, D., 1981, "Stormwater Hydrology and Drainage." In Chow, V.T. (Ed.), Developments in Water Science, vol. 14. Elsevier, Amsterdam.

12. Terstriep, M.L., and Stall, J.B., 1974, "The Illinois Urban Drainage Area Simulator, ILLUDAS.” Illinois State Water Survey Bulletin 58.

13. Wallingford Software Ltd., 2000, User Guide and Help System for HYDROWORKS Ver. 6.0 User's Manual, Oxon, UK.

14. Yen, B. C. and Akan, A. O., 1999, "Hydraulic design of urban drainage systems." In: Mays, L.W. (Ed.), Hydraulic Design Handbook, McGraw-Hill Inc., New York.

15. Yen, B. C., 1986, "Hydraulics of Sewers." In: Yen, B.C. (Ed.), Advances in Hydroscience, vol. 14. Academic Press, New York, pp. 1-123. 


\title{
NOMENCLATURE
}

\author{
$A$ area of interest $\left[\mathrm{m}^{2}\right]$ \\ $A_{b} \quad$ built-up area of interest $\left[\mathrm{m}^{2}\right]$ \\ $\beta \quad$ linear detaining ratio \\ $d \quad$ water depth of overland flow [m]
}

$d\left(x_{k}, y_{k}, t\right) \quad$ water depth of overland flow at location $\left(x_{k}, y_{k}\right)$ and time $t \quad[\mathrm{~m}]$

$\delta \quad$ Dirac delta function

$g \quad$ gravitational acceleration $\left[\mathrm{m} / \mathrm{s}^{2}\right]$

$h \quad$ water stage on ground surface [m]

$I$ the intensity of rainfall excess $[\mathrm{m} / \mathrm{s}$ ]

n Manning's roughness of ground surface

$Q_{d}\left(x_{k}, y_{k}\right)$ design capacity of inlet at point $\left(x_{k}, y_{k}\right)\left[\mathrm{m}^{3} / \mathrm{s}\right]$

$q_{i}(x, y, t)$ rate of water leaving unit area of ground surface $\left[\mathrm{m}^{3} /\left(\mathrm{s} \cdot \mathrm{m}^{2}\right)\right]$

$Q_{i}\left(x_{k}, y_{k}, t\right)$ discharge of inlet at point $\left(x_{k}, y_{k}\right)$ and time $t\left[\mathrm{~m}^{3} / \mathrm{s}\right]$

$q_{s}(x, y, t)$ rate of water entering unit area of ground surface $\left[\mathrm{m}^{3} /\left(\mathrm{s} \cdot \mathrm{m}^{2}\right)\right]$

$Q_{s}\left(x_{k}, y_{k}, t\right)$ discharge of manhole surcharge at point $\left(x_{k}, y_{k}\right)$ and time $t\left[\mathrm{~m}^{3} / \mathrm{s}\right]$

$S_{f x} \quad$ friction slope along the $\mathrm{x}$ direction of overland flow

$S_{f y} \quad$ friction slope along the y direction of overland flow 
Please cite as: Hsu MH, Chen SH, Chang TJ. (2002) Dynamic inundation simulation of storm water interaction between sewer system and overland flows, Journal of The Chinese Institute of Engineers, 25(2) 171-177. DOI:10.1080/02533839.2002.9670691

$t \quad$ time $[\mathrm{s}]$

$u \quad$ velocity component in the $\mathrm{x}$ direction of overland flow $[\mathrm{m} / \mathrm{s}]$

$v \quad$ velocity component in the y direction of overland flow $[\mathrm{m} / \mathrm{s}]$

$z$ ground surface elevation $[\mathrm{m}]$ 
Please cite as: Hsu MH, Chen SH, Chang TJ. (2002) Dynamic inundation simulation of storm water interaction between sewer system and overland flows, Journal of The Chinese Institute of Engineers, 25(2) 171-177. DOI:10.1080/02533839.2002.9670691

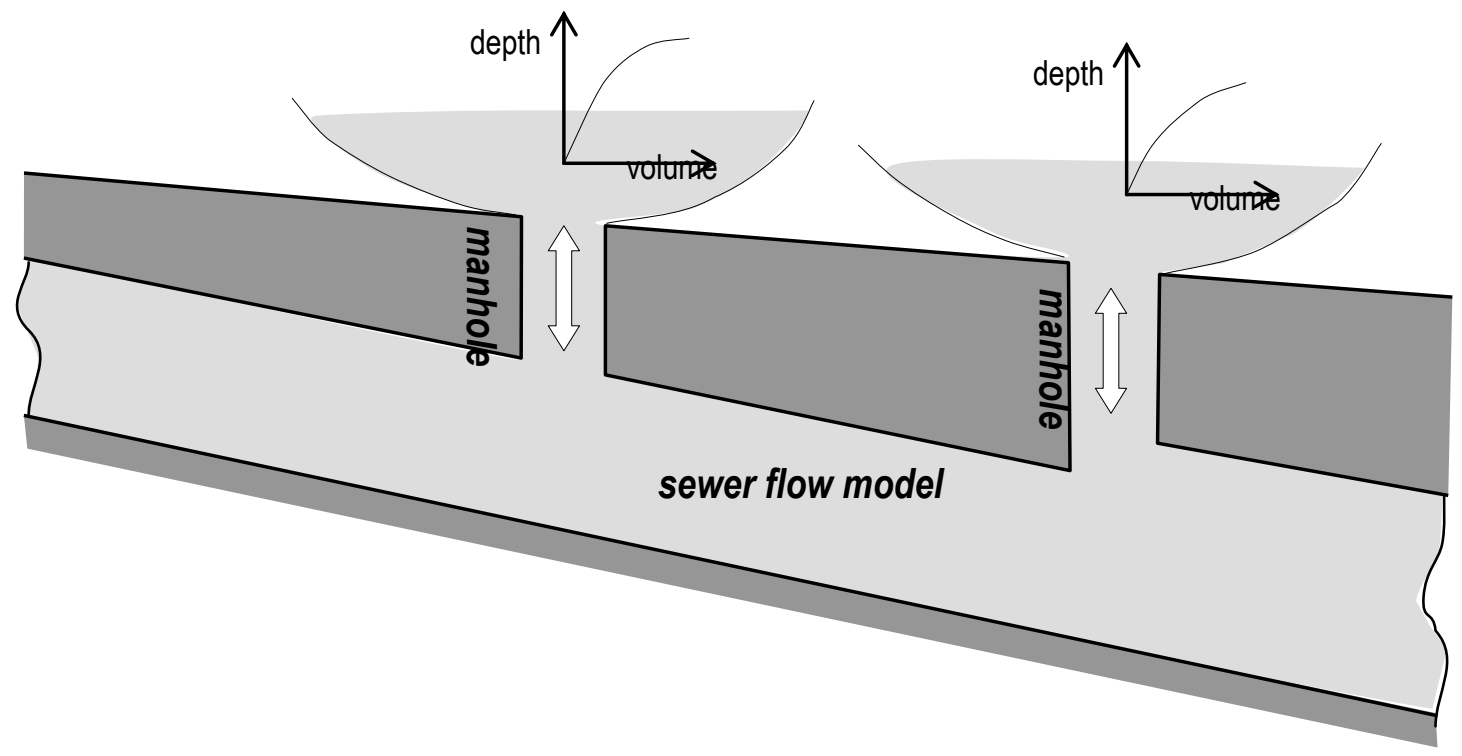

(a)

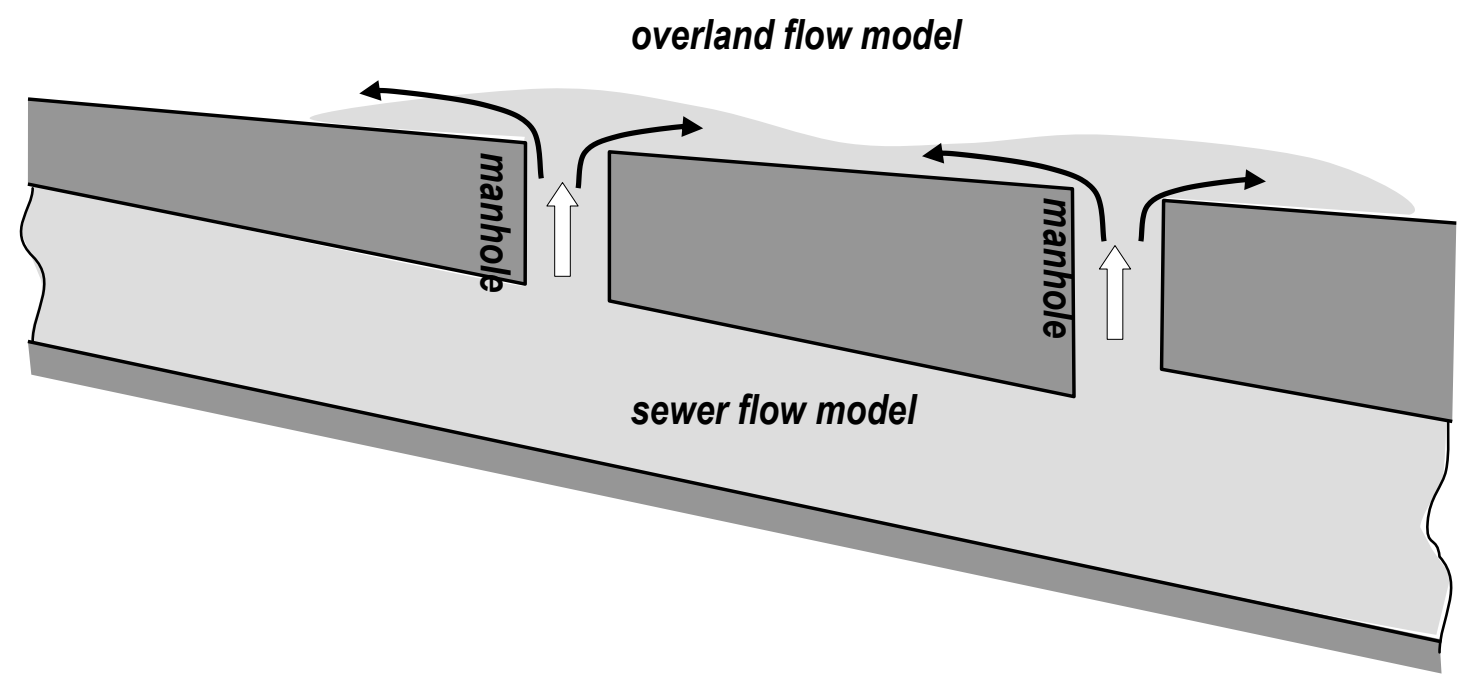

(b) 


\section{overland flow model}

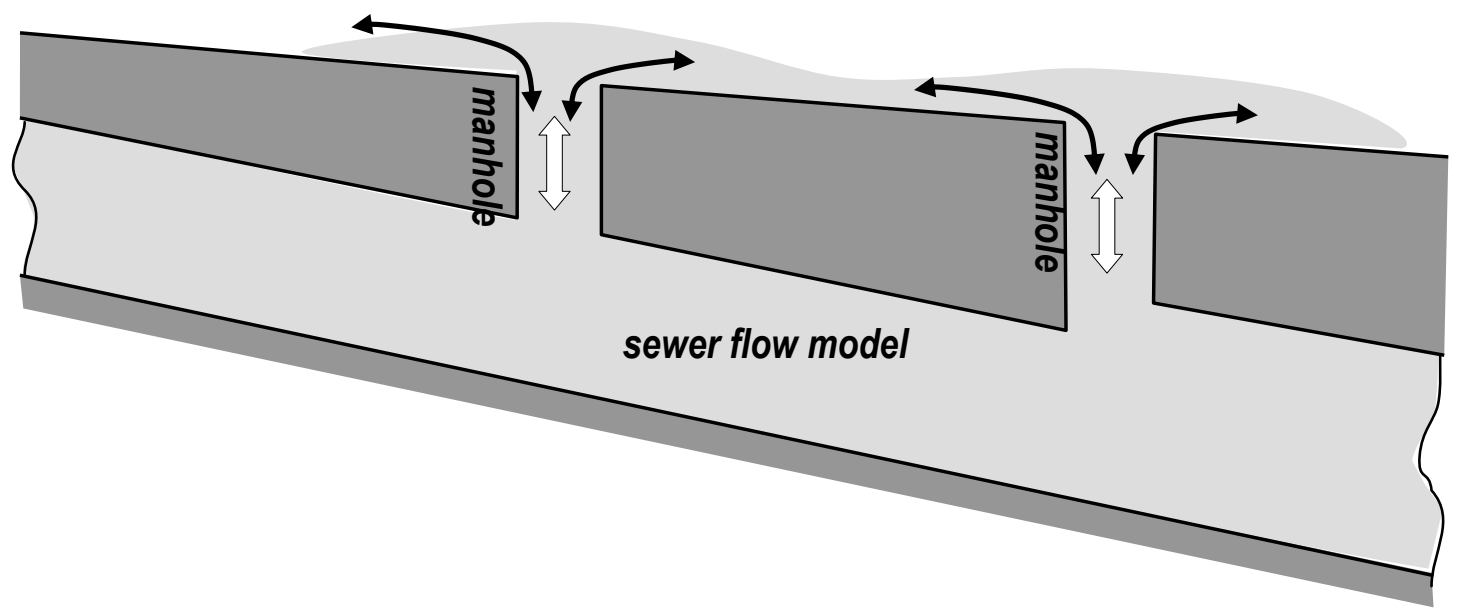

(c)

Fig. 1. Three categories of combined sewer and overland flow model

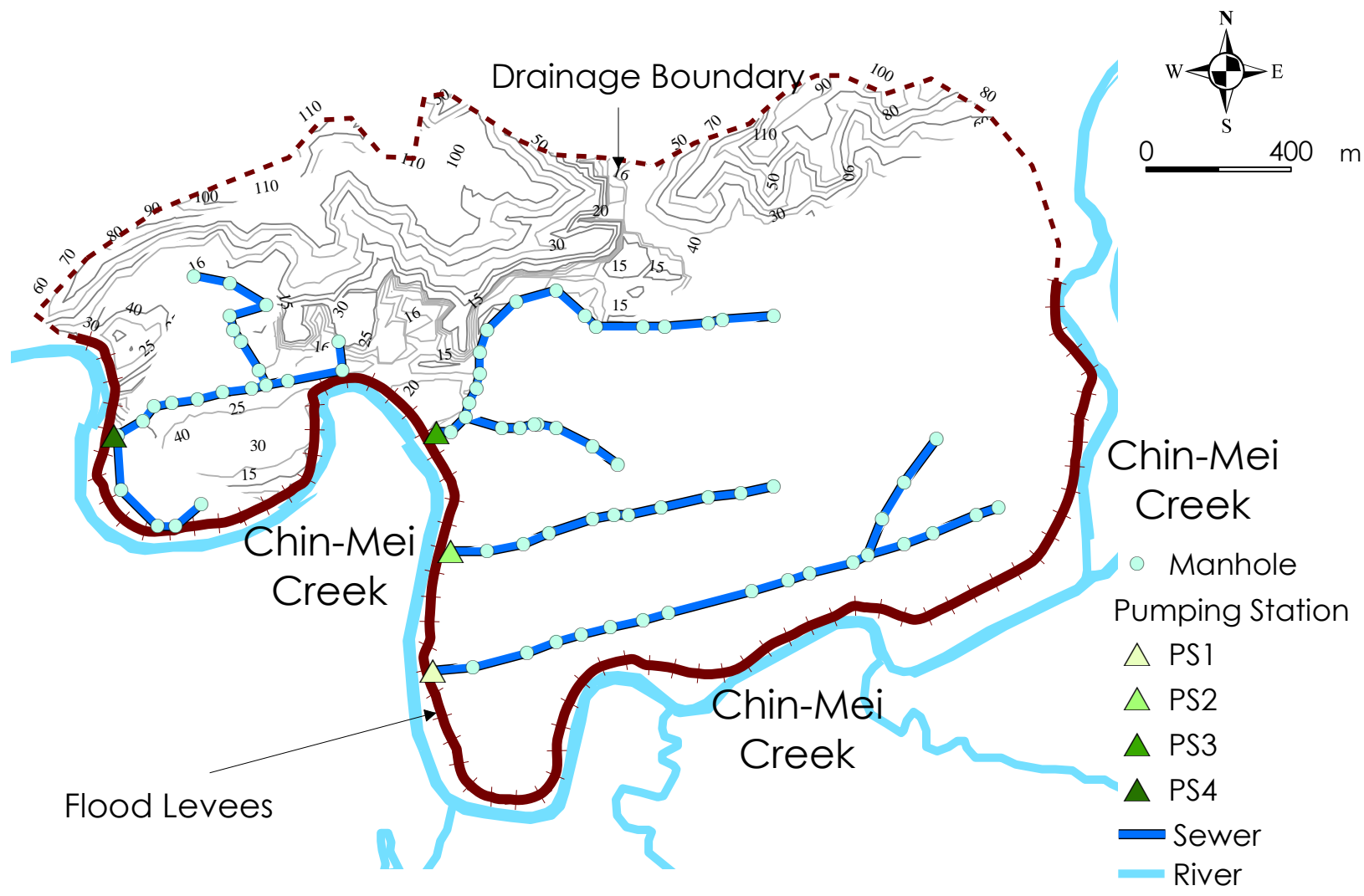

Fig. 2. Manholes, Sewers and topology contours of Mucha area

(The numbers are elevation in meters) 


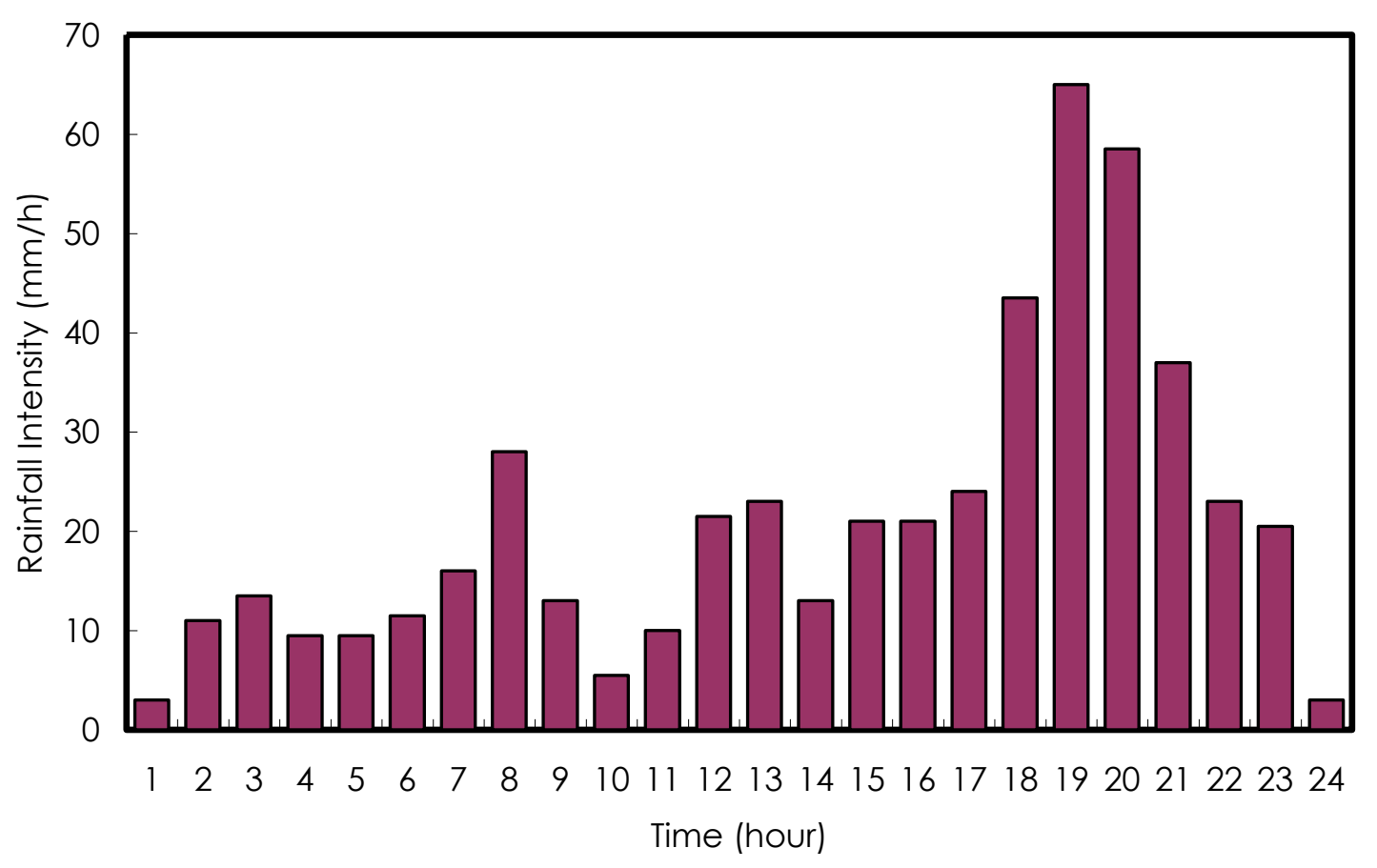

Fig. 3. Rainfall hyetograph of the Typhoon Xangsane event

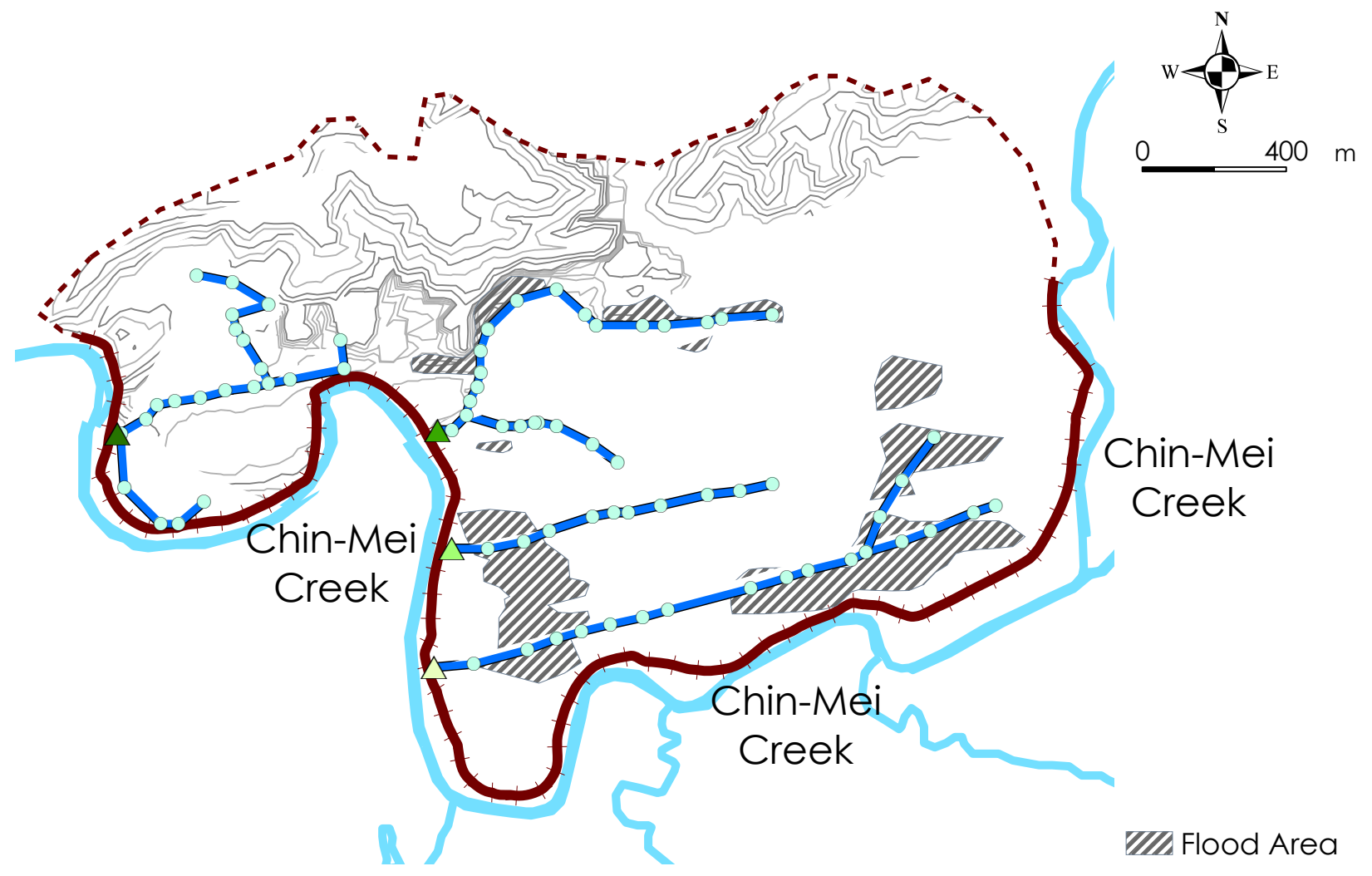


Fig. 4. Surveyed flood extent from the Typhoon Xangsane event

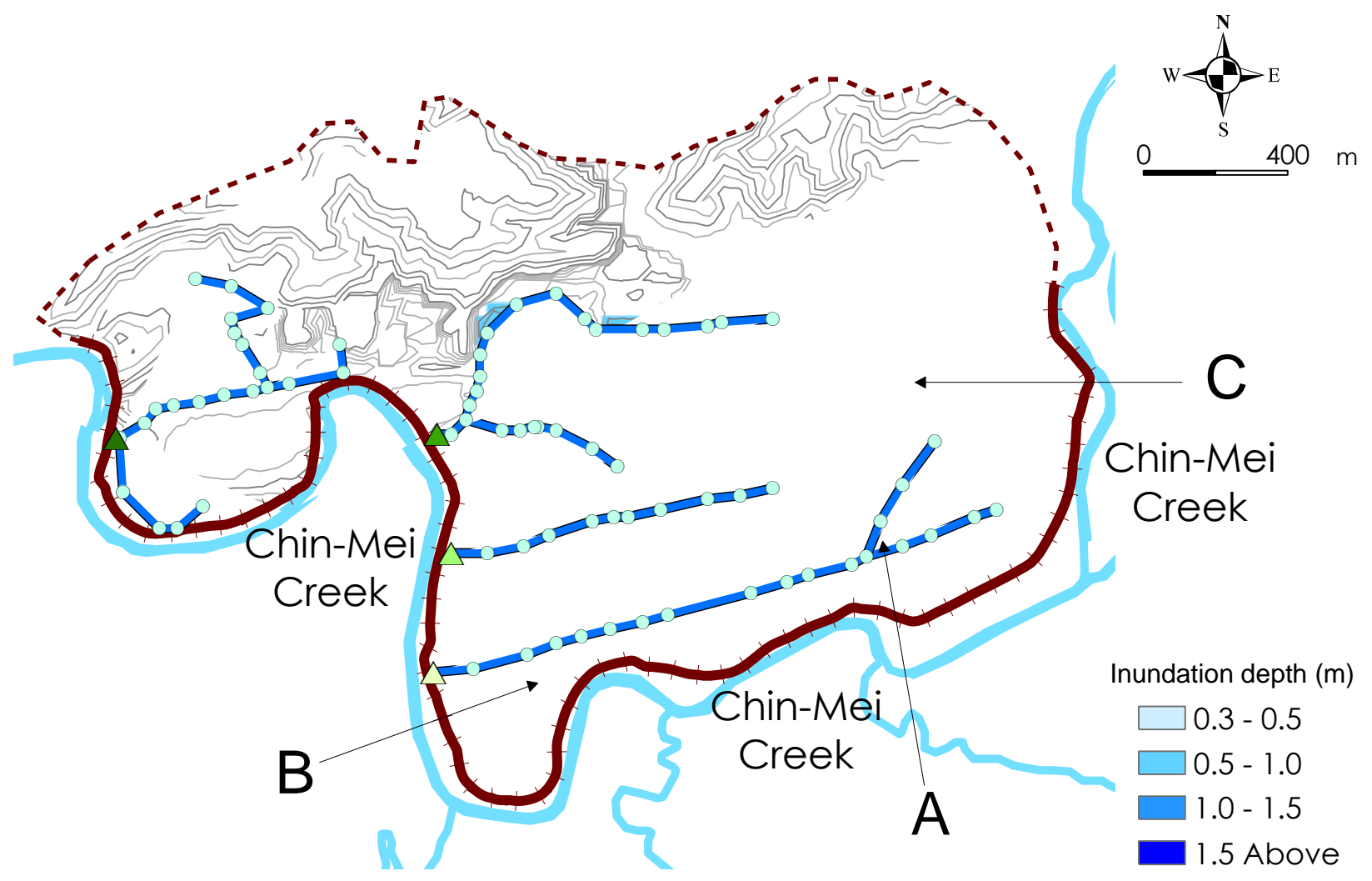

Fig. 5. Simulated flood extent and depth during the Typhoon Xangsane event 
Please cite as: Hsu MH, Chen SH, Chang TJ. (2002) Dynamic inundation simulation of storm water interaction between sewer system and overland flows, Journal of The Chinese Institute of Engineers, 25(2) 171-177. DOI:10.1080/02533839.2002.9670691

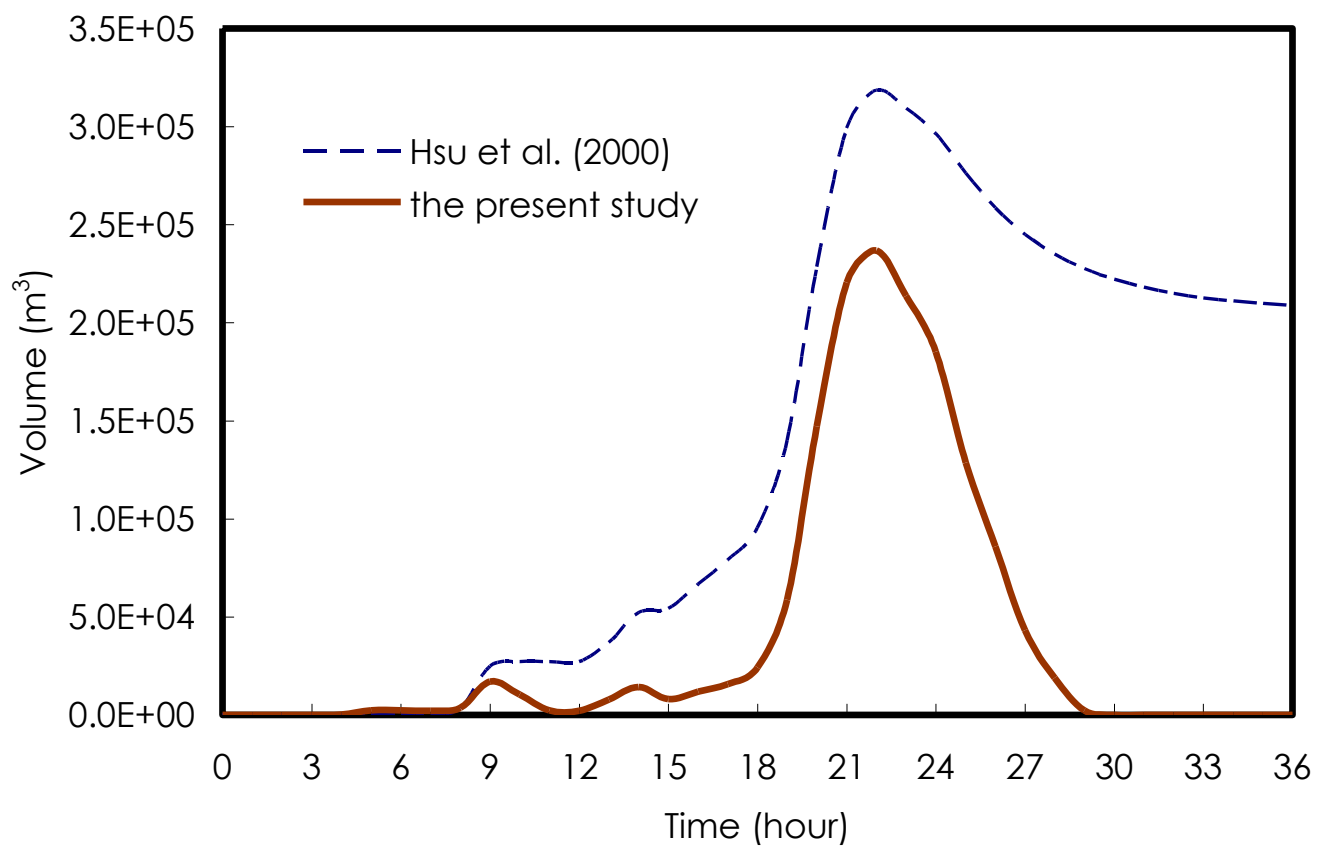

Fig. 6. Comparison of total cumulative inundation volume of Mucha area during the Typhoon Xangsane event

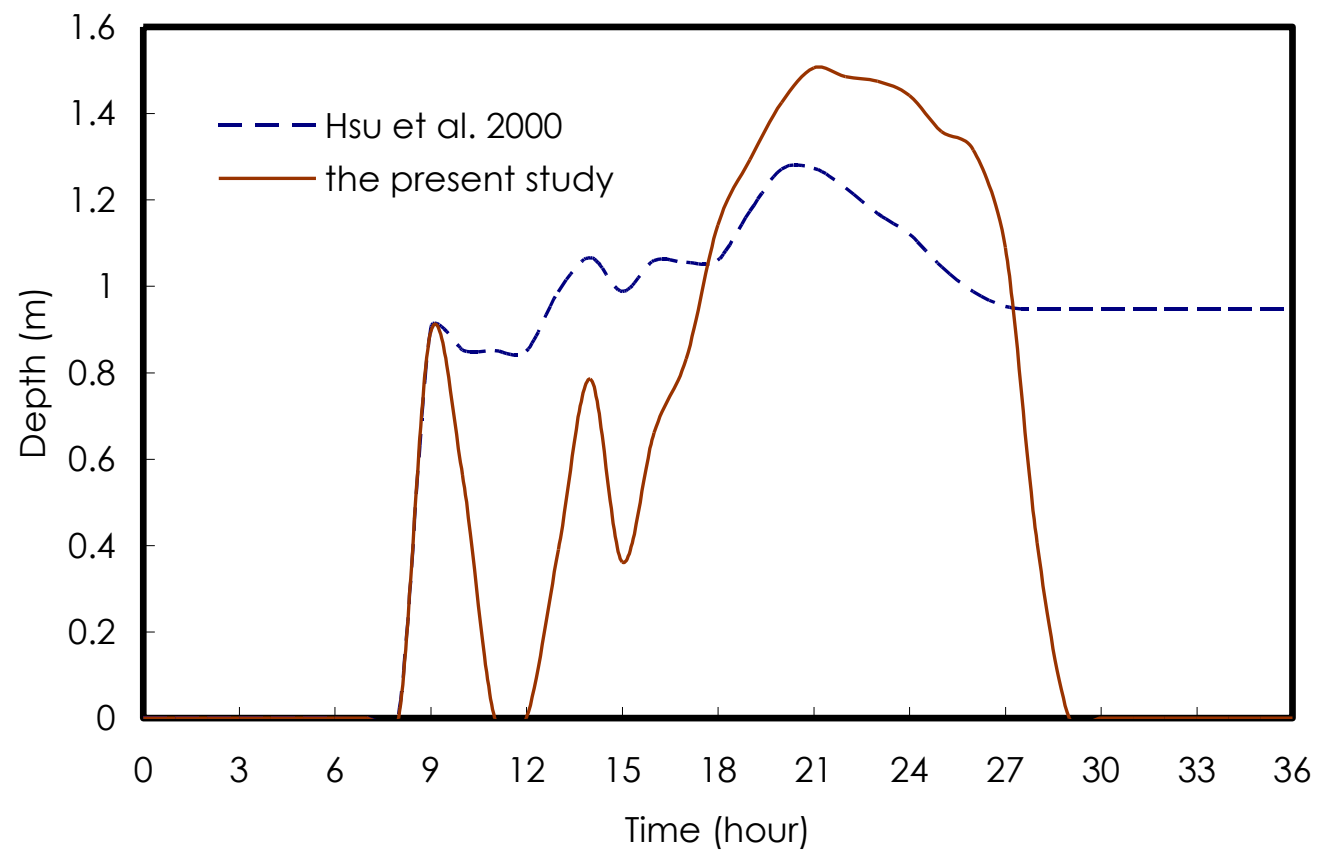


Fig. 7. Comparison of inundation depth variation at point A during the Typhoon Xangsane event

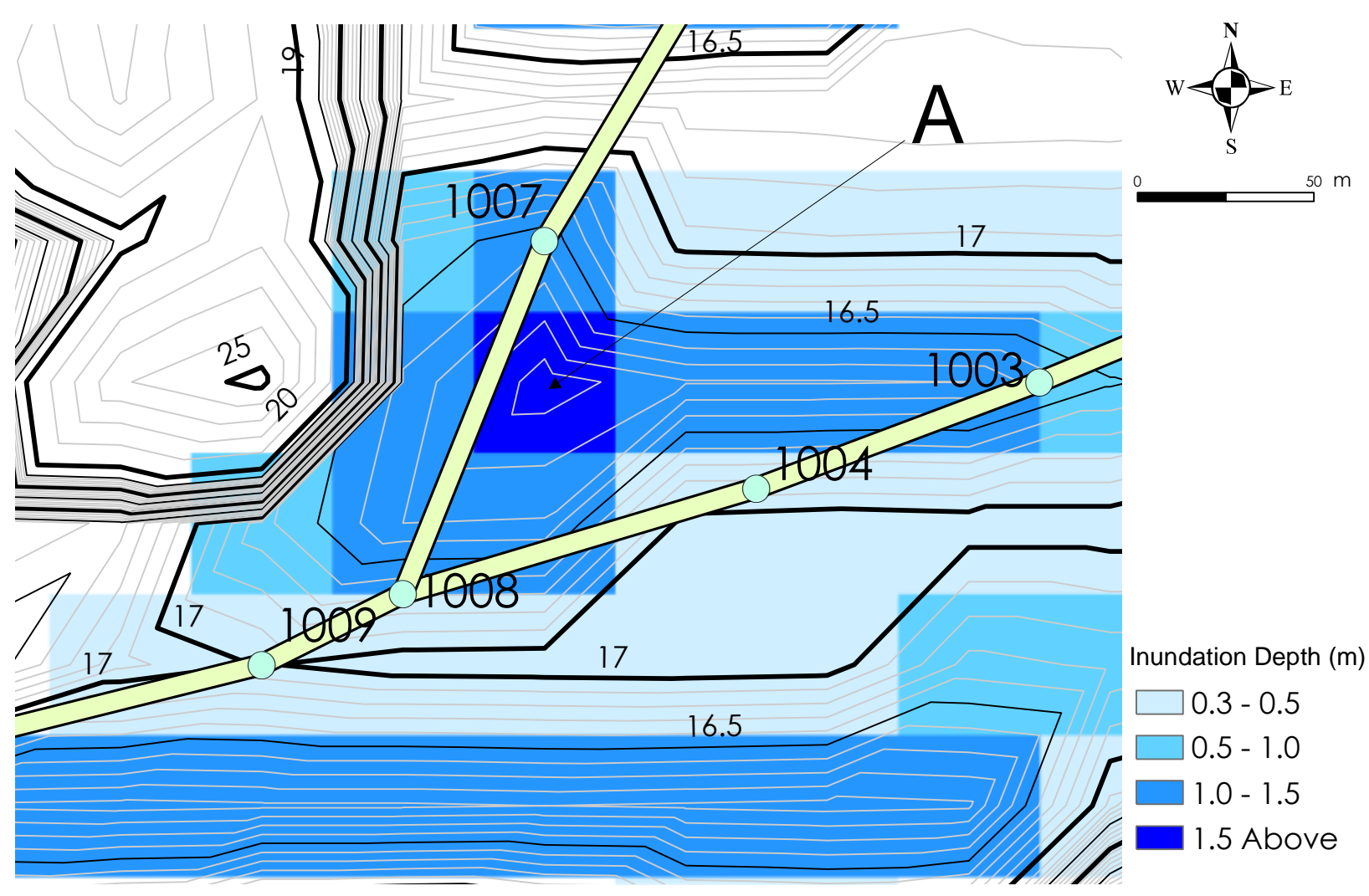

Fig. 8. The ground elevation and inundation depth around point A obtained by the present model 
Please cite as: Hsu MH, Chen SH, Chang TJ. (2002) Dynamic inundation simulation of storm water interaction between sewer system and overland flows, Journal of The Chinese Institute of Engineers, 25(2) 171-177. DOI:10.1080/02533839.2002.9670691

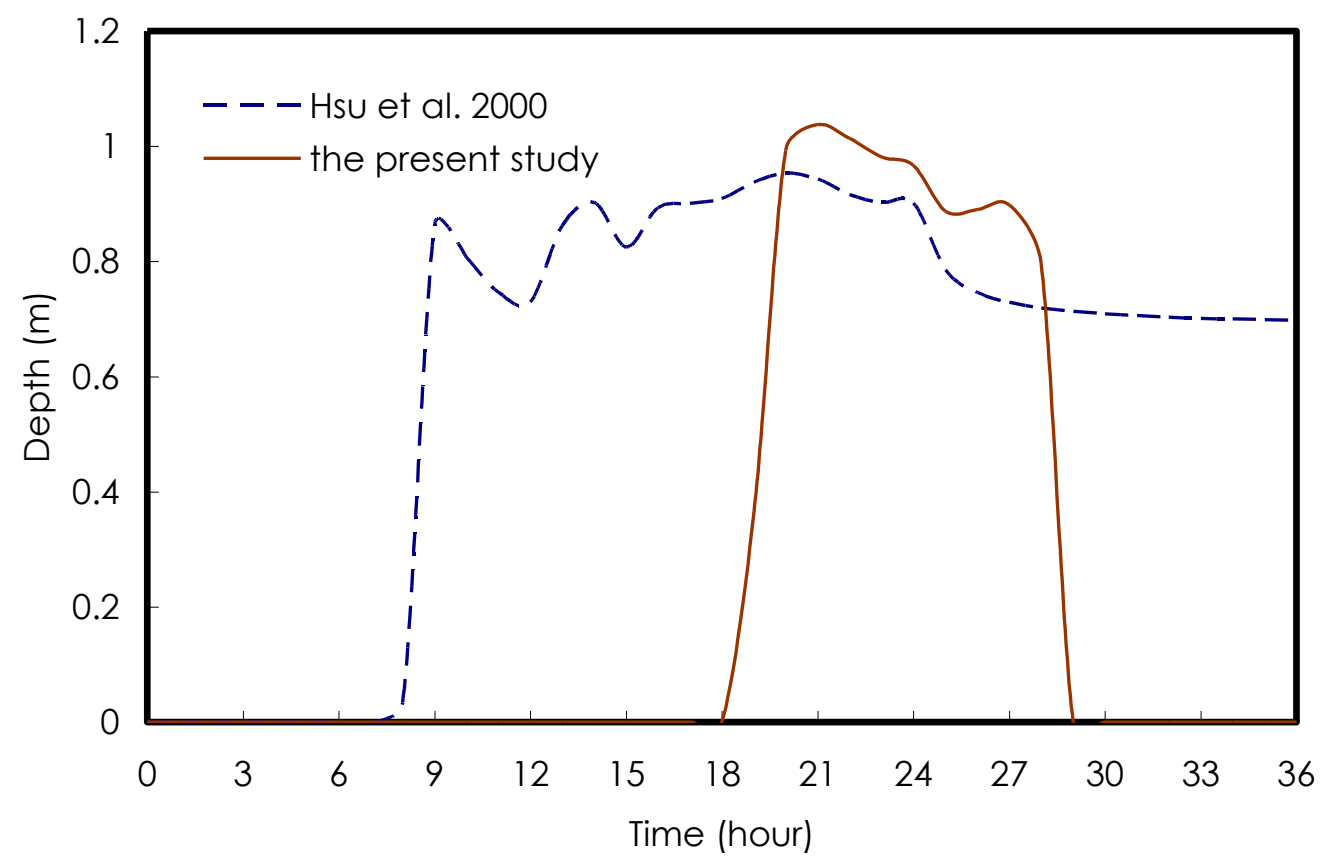

Fig. 9. Comparison of inundation depth variation at point B during the Typhoon Xangsane event 


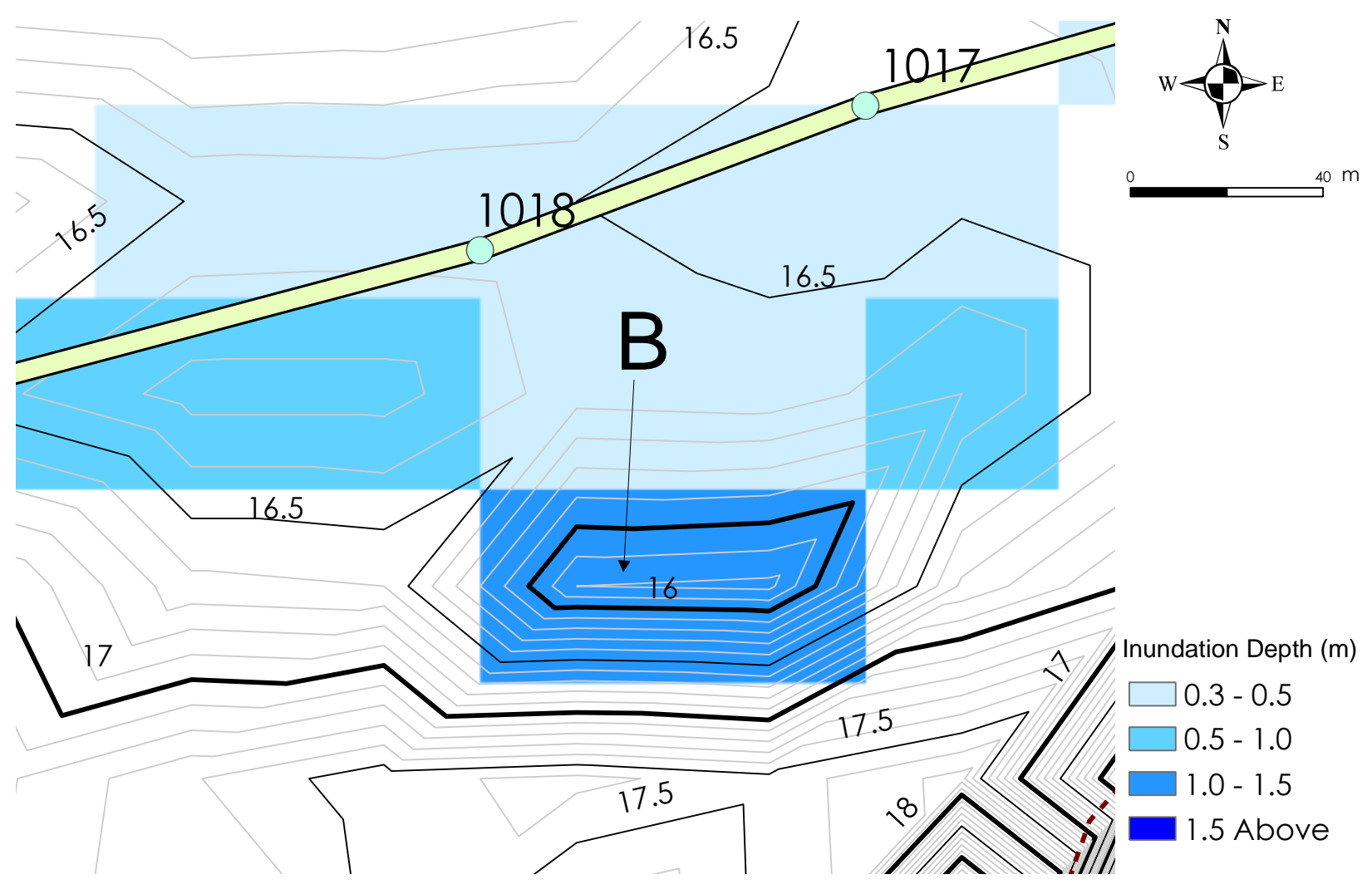

Fig. 10. The ground elevation and inundation depth around point B obtained by the present model 
Please cite as: Hsu MH, Chen SH, Chang TJ. (2002) Dynamic inundation simulation of storm water interaction between sewer system and overland flows, Journal of The Chinese Institute of Engineers, 25(2) 171-177. DOI:10.1080/02533839.2002.9670691

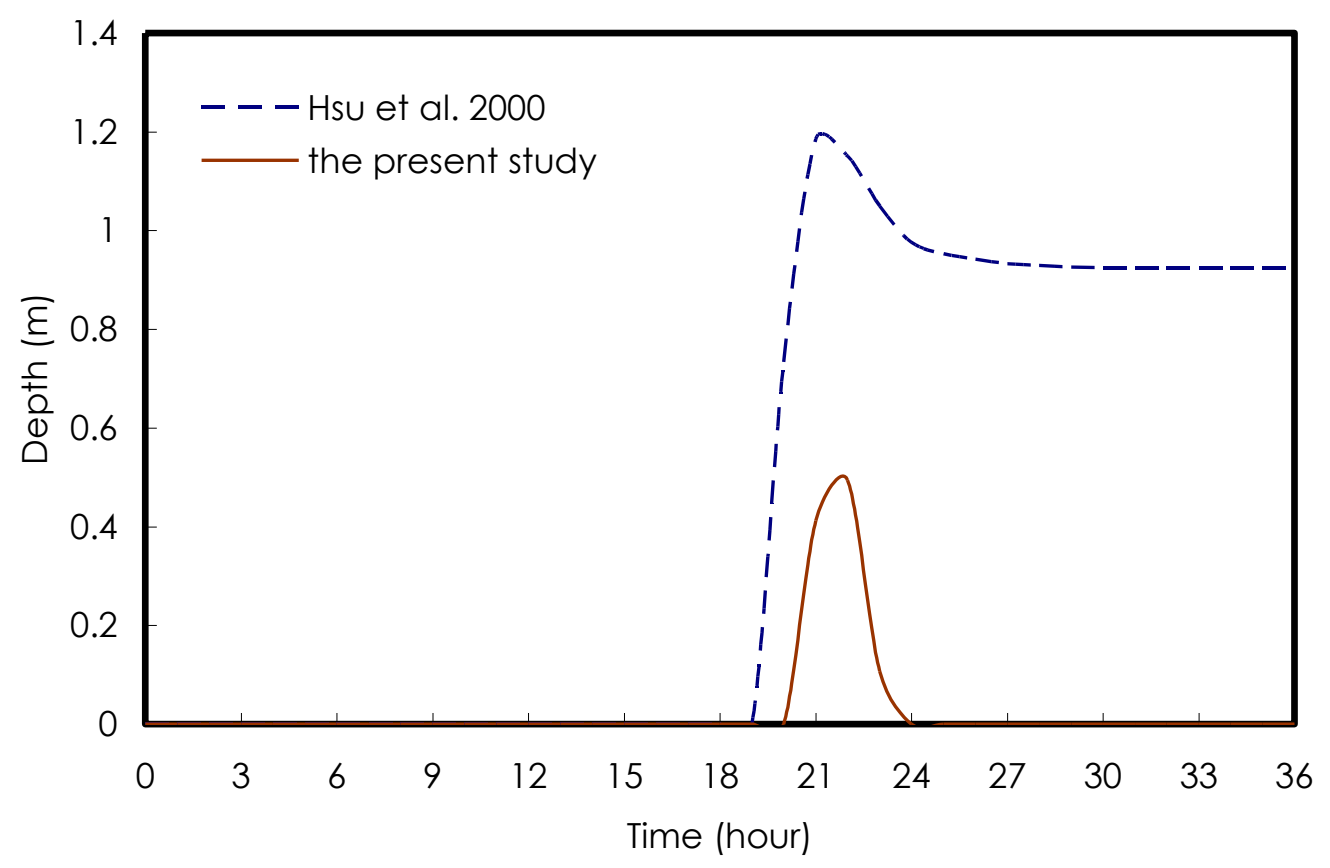

Fig. 11. Comparison of inundation depth variation at point $\mathrm{C}$ during the Typhoon Xangsane event 


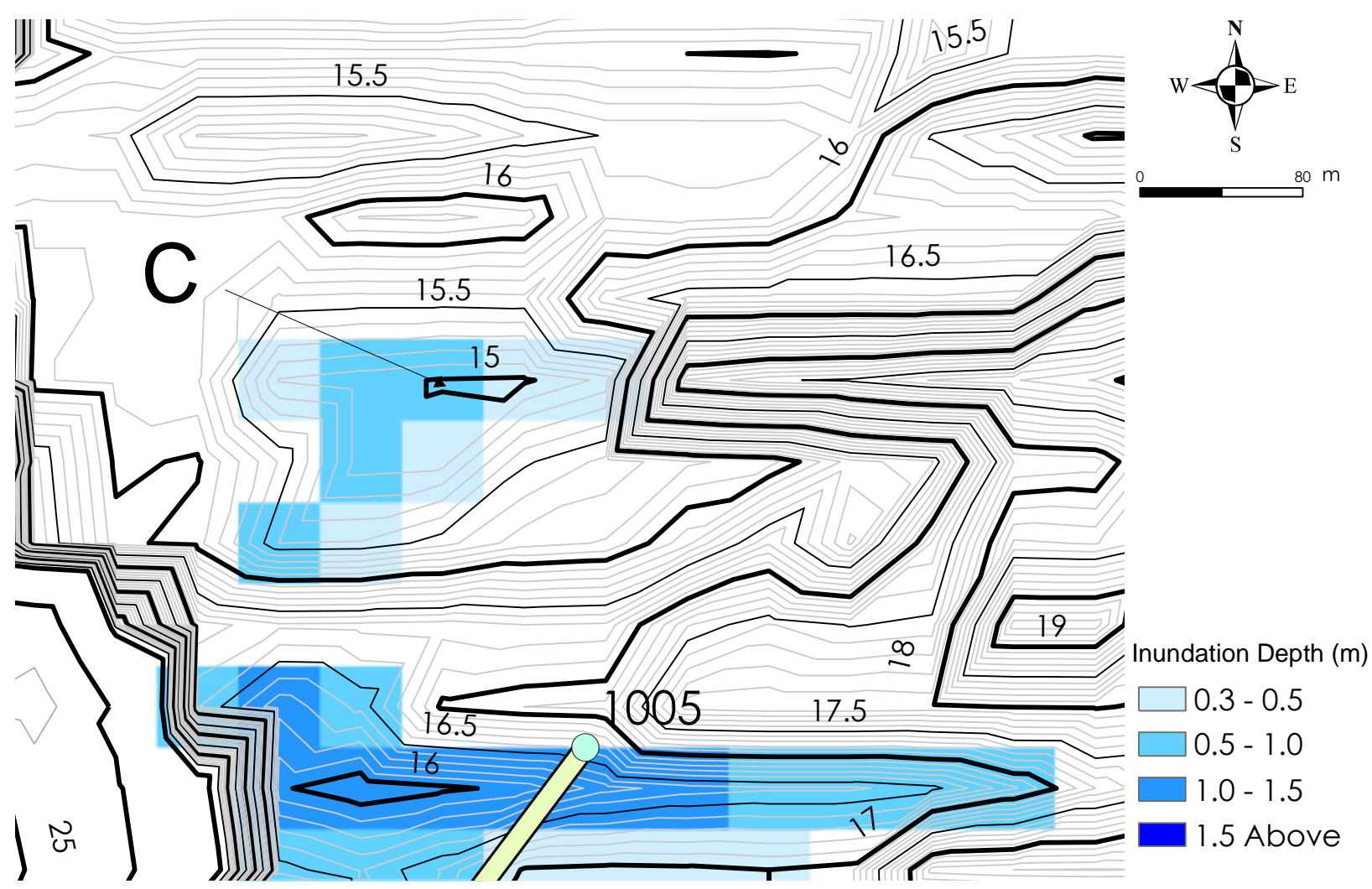

Fig. 12. The ground elevation and inundation depth around point $\mathrm{C}$ obtained by the present model 
Please cite as: Hsu MH, Chen SH, Chang TJ. (2002) Dynamic inundation simulation of storm water interaction between sewer system and overland flows, Journal of The Chinese Institute of Engineers, 25(2) 171-177. DOI:10.1080/02533839.2002.9670691

\title{
雨水下水道與漫地流間水流互動之動態淹水模擬
}

\author{
許銘熙 陳宣宏 張倉榮
}

\section{國立台灣大學生物環境系統工程學系}

\begin{abstract}
摘要
本文結合二維零慣性漫地流與雨水下水道經理模式, 發展一個適用於計算都市地區之都市淹 水模式, 並應用於模擬都會地區之淹水。本模式演算包括地表逕流量及下水道溢流量, 以反應水流 在下水道及地表間雙向互動之流況。本研究以 2000 年 11 月造成台北市木柵地區嚴重淹水的象神颱 風事件進行驗証, 並與過去模式進行比較, 顯示本模式具有較佳之模擬精度, 可用以提供規劃更可 靠的防災措施。
\end{abstract}

關鍵詞：都市淹水模式、雨水下水道、漫地流 